agriTECH, 41 (1) 2021, 58-70

\title{
Uji Keaslian Kopi Bubuk Spesialti Arabika Gayo Aceh Menggunakan Spektroskopi UV dan Kemometrika
}

\author{
Authentication of Ground Roasted Specialty Gayo Arabica Coffee from Aceh using UV Spectroscopy and \\ Chemometrics
}

\author{
Diding Suhandy ${ }^{1 *}$, Meinilwita Yulia² \\ ${ }^{1}$ Jurusan Teknik Pertanian, Fakultas Pertanian, Universitas Lampung, Jl. Prof. Dr. Soemantri Brojonegoro No.1 Gedong \\ Meneng, Lampung 35145, Indonesia \\ 2Jurusan Teknologi Pertanian, Politeknik Negeri Lampung, Jl. Soekarno Hatta No.10 Rajabasa, Lampung 35141, \\ Indonesia \\ *Penulis korespondensi: Diding Suhandy, Email: diding.sughandy@fp.unila.ac.id
}

Tanggal submisi: 31 Mei 2020; Tanggal revisi: 16 Agustus 2020 Tanggal penerimaan: 8 September 2020

\begin{abstract}
ABSTRAK
Kopi arabika Gayo merupakan salah satu kopi spesialti dengan indikasi geografis yang menjadi salah satu target pengoplosan. Beras yang jumlahnya sangat banyak tersedia di Indonesia sangat potential menjadi bahan pengoplos kopi Gayo. Pada penelitian ini, kopi bubuk arabika Gayo dioplos atau dicampur menggunakan beras bubuk sangrai dengan kadar pengoplosan sebesar 10-50\% (w/w). Sebanyak 197 sampel kopi Gayo murni dan campuran disiapkan sebagai sampel penelitian. Data spektra seluruh sampel diukur menggunakan spektrofotometer UVvisible pada panjang gelombang $200-400 \mathrm{~nm}$. Spektra original ditransformasi menggunakan tiga algoritma yaitu moving average, standard normal variate dan Savitzky-Golay derivative. Model kalibrasi PLS (partial least square) dibangun menggunakan algoritma PLS1 dan divalidasi menggunakan metode validasi $t$-test. Model kalibrasi PLS terbaik diperoleh untuk spektra transformasi dengan interval 250-390 nm dengan sampel terpilih yaitu tanpa sampel pencilan. RPD (ratio prediction to deviation) dan RER (range error ratio) sebesar 3,87 dan 10,71 diperoleh untuk model kalibrasi PLS terbaik. Prediksi persentase beras dalam campuran kopi Gayo dilakukan dengan menggunakan model kalibrasi PLS terbaik dan menghasilkan prediksi yang bisa diterima dengan nilai bias dan SEP (standard error of prediction) yang rendah.
\end{abstract}

Kata kunci: Uji keaslian; kopi Gayo; indikasi geografis (GIs); regresi PLS; spektroskopi UV

\begin{abstract}
Gayo arabica coffee is one of the specialty breeds with a geographic indication of origins (GIs) targeted of adulteration. Also, ground roasted rice serves as a potential adulterant and is readily available in huge quantities in Indonesia. In this research, Gayo arabica specialty coffee was contaminated with $10-50 \%(\mathrm{w} / \mathrm{w})$ of ground roasted rice. A total of 197 samples of genuine and infected grades were prepared, and the entire spectra were acquired using a UV-visible spectrophotometer across a range of 200-400 nm. In addition, spectral preprocessing was applied with three algorithms, termed moving average, standard normal variate, and Savitzky-Golay derivative. Subsequently, PLS (partial least square) calibration model was developed with PLS1 algorithm and then validated by the t-test method. The best PLS calibration model was achieved at a transformed spectral data in an interval
\end{abstract}


of 250-390 nm by selected samples, without outliers and the RPD (ratio prediction to deviation) of 3.87 as well as RER (range error ratio) of 10.71 were separately obtained. Furthermore, the prediction was performed using the best PLS calibration model resulting in an acceptable consequence with low bias and SEP (standard error of prediction).

Keywords: Authentication; Gayo coffee; geographic indications (GIs); PLS regression; UV spectroscopy

\section{PENDAHULUAN}

Kopi merupakan salah satu komoditas pertanian dunia yang bernilai ekonomi tinggi. Indonesia menjadi salah satu penghasil kopi penting dan berada di urutan keempat di dunia untuk penghasil kopi robusta dan arabika dengan total produksi sebesar 0,6 juta ton di tahun 2019 (ICO, 2019). Salah satu daerah penghasil kopi arabika di Indonesia adalah Provinsi Aceh dengan produksi kopi sebesar 54,31 ribu ton dan menyumbang $31,88 \%$ dari produksi kopi nasional Indonesia pada tahun 2017 (Widaningsih, 2019). Salah satu kopi Aceh yang terkenal adalah kopi arabika Gayo yang ditanam di dataran tinggi Gayo yang meliputi beberapa daerah seperti Kabupaten Aceh Tengah, Kabupaten Bener Meriah dan Kabupaten Gayo Lues dengan rata-rata ketinggian sekitar 900-1700 meter di atas permukaan laut. Kopi arabika Gayo Aceh telah mendapatkan sertifikat indikasi geografis atau geographic indication of origins (GIs) (IG No. ID G 000000 005) sejak tanggal 28 April 2010 (DGIP, 2020). Kopi dengan indikasi geografis (GIs) merupakan kopi yang dikenal sebagai spesialti kopi yaitu kopi yang memiliki nilai skor di atas 80 menurut hasil uji cupping test yang dilakukan oleh penilai dengan sertifikat $Q$ grader. Sebagai kopi dengan cita rasa tinggi, kopi spesialti arabika Gayo memiliki harga yang lebih mahal dibandingkan dengan kopi biasa. Alasan ekonomi yaitu untuk mendapatkan keuntungan yang lebih banyak membuat kopi arabika Gayo menjadi salah satu produk pertanian yang rawan dipalsukan atau dioplos.

Menurut Bansal dkk. (2017) yang dimaksud dengan pemalsuan pangan salah satunya adalah proses menurunkan kualitas pangan baik dengan sengaja maupun tidak dengan cara mengganti sebagian komponen pangan dengan beberapa bahan lain yang lebih rendah kualitasnya (yang kemudian dikenal sebagai bahan pencampur atau adulterant). Secara khusus pemalsuan kopi dilihat dari sisi bahan yang dicampurkan dapat dibedakan menjadi tiga bentuk yaitu pertama adalah pemalsuan kopi dengan cara menambahkan bahan bukan kopi seperti jelai (barley), gula merah, karamel, sekam kopi, jagung, kedelai, beras dan sebagainya ke dalam kopi murni. Pemalsuan jenis kedua adalah pemalsuan kopi dengan cara mencampurkan dua jenis kopi biasanya antara biji kopi yang mahal dengan biji kopi yang murah misalnya biji kopi spesialti arabika dicampur dengan biji kopi biasa robusta. Pemalsuan jenis ketiga adalah pemalsuan kopi dalam bentuk pencampuran antara kopi dengan indikasi geografis atau geographic indication of origins (GIs) tertentu yang mahal dengan kopi biasa non-GIs misalnya kopi arabika Gayo Aceh dicampur dengan kopi biasa non-GIs (Briandet dkk., 1996; Sano dkk., 2003). Dilihat dari kondisi bahan saat terjadinya pencampuran, pemalsuan atau pengoplosan kopi terjadi dalam tiga bentuk biji kopi yaitu saat masih biji kopi hijau (green bean), saat biji kopi sudah disangrai (roasted bean) dan saat biji kopi sudah disangrai dan digiling atau kopi bubuk (ground roasted bean).

Pemalsuan kopi bubuk menjadi salah satu bentuk pemalsuan yang sulit dideteksi secara visual menggunakan mata biasa. Sehingga secara visual, metode microscopy banyak diadopsi untuk deteksi pencampuran pada kopi bubuk. Hanya saja pada kopi bubuk, bentuk dan warna kopi dan bahan pencampurnya menjadi sangat sulit dibedakan (Reis dkk., 2013a). Beberapa metode analisis telah diujicobakan dan dilaporkan sebagai alternatif untuk deteksi adanya pemalsuan pada kopi bubuk. Salah satunya adalah dengan menggunakan metode kromatografi. Garcia dkk. (2009) menggunakan metode kromatografi high-performance anionic exchange chromatographypulse amperometric detection (HPAEC-PAD) untuk mendeteksi adanya pencampuran sekam kopi dan jagung yang dicampurkan pada kopi bubuk. Metode kromatografi lain seperti solid phase micro-extractiongas chromatography-mass spectrometry (SPME-GCMS) juga digunakan untuk mendeteksi pencampuran gandum pada kopi bubuk (Oliviera dkk., 2009). Pauli dkk. (2014) juga menggunakan metode HPLC-HPAEC$P A D$ yang dikombinasikan dengan kemometrika PCA (principal component analysis) dan LDA (linear discriminant analysis) untuk mendeteksi pencampuran kedelai dan gandum pada kopi bubuk. Meskipun efektif, metode kromatografi merupakan metode yang memiliki beberapa kelemahan seperti waktu analisis yang sangat lama, mahal, dan melibatkan proses persiapan sampel yang cukup lama dan melelahkan sehingga sulit diaplikasikan sebagai metode analisis untuk uji keaslian kopi bubuk secara rutin (Reis dkk., 2013b). 
Metode lain yang digunakan untuk deteksi pencampuran kopi bubuk adalah metode analisis berbasis spektroskopi seperti near infrared (NIR), mid infrared, nuclear magnetic resonance (NMR) dan spektroskopi Raman. Winkler-Moser dkk. (2015) melaporkan penggunaan spektroskopi NIR untuk deteksi keaslian kopi bubuk asal Brasil yang dicampur dengan jagung dengan persentase campuran 1-20\%. Spektroskopi mid infrared pada gelombang elektromagnetik $4000-700 \mathrm{~cm}^{-1}$ digunakan untuk deteksi keberadaan beberapa bahan pengoplos seperti bubuk jagung, sekam kopi dan jelai (barley) yang dicampurkan ke dalam kopi bubuk asal Brasil (Reis dkk., 2017). Spektroskopi NMR digunakan untuk uji keaslian kopi bubuk arabika asal Brasil yang dicampur dengan bubuk jagung, sekam kopi, jelai dan kacang kedelai (Ribeiro dkk., 2017). Spektroskopi Raman juga dilaporkan berhasil mendeteksi perbedaan antara bubuk kopi arabika, kopi robusta dan campuran antara kopi arabika dan robusta (Wermelinger dkk., 2011). Kelebihan metode spektroskopi tersebut adalah cepat pengukurannya, persiapan sampel sangat minimal atau bahkan tanpa perlu persiapan sampel dan hasil pengukuran cukup akurat. Namun demikian salah satu kekurangan metode spektroskopi yang disebutkan di atas adalah mahalnya alat spektroskopi yang digunakan. Hal ini tentu saja menjadi salah satu faktor yang bisa menghambat hilirisasi teknologi uji keaslian kopi spesialti Indonesia jika menggunakan metode spektroskopi seperti di atas.

Saat ini metode spektroskopi berbasis UV-visible dengan daerah panjang gelombang 190-700 nm mulai banyak digunakan pada proses uji keaslian pangan seperti madu (Roshan dkk., 2013), teh (Aboulwafa dkk., 2019), dan kopi. Untuk kopi bubuk, spektroskopi UV telah digunakan untuk membedakan kopi luwak dan kopi biasa (Suhandy \& Yulia, 2017a), kopi lanang dan kopi biasa (Suhandy dan Yulia, 2017; Suhandy dkk., 2017) serta penentuan kandungan kopi arabika dan robusta dalam kopi campuran arabika-robusta (Dankowska dkk., 2017). Kelebihan metode spektroskopi UV adalah alatnya yang digunakan yaitu spektrofotometer UV lebih terjangkau harganya dibandingkan dengan spektroskopi yang lain. Pengukurannya pun relatif cepat karena proses persiapan sampel yang minimal dan hasil pengukuran cukup akurat dan dapat diandalkan. Dari penelusuran pustaka, penggunaan spektroskopi UV untuk kuantifikasi persentase campuran pada kopi spesialti Indonesia seperti kopi Gayo masih sangat terbatas. Sehingga pada penelitian ini, dilakukan investigasi potensi penggunaan spektroskopi UV sebagai metode analisis baru untuk kuantifikasi persentase beras (bubuk) yang dicampurkan ke dalam kopi bubuk
Gayo. Teknik yang dibangun ini dapat digunakan untuk membangun sistem uji keaslian kopi Gayo sebagai salah satu kopi spesialti asal Indonesia.

\section{METODE PENELITIAN}

\section{Sampel Kopi Gayo dan Bahan Pencampurnya}

Bahan sampel kopi arabika Gayo dalam bentuk biji hijau (green bean) dibeli dari kelompok petani di Desa Pondok Gajah, Kecamatan Bandar, Kabupaten Bener Meriah, Aceh sedangkan beras sebagai bahan pencampur ( filler) dibeli dari pedagang lokal di kota Bandar Lampung. Kopi Gayo dan beras disangrai pada mesin yang sama (home coffee roaster) pada kondisi yang sama yaitu suhu sebesar $190-210{ }^{\circ} \mathrm{C}$ selama 10 menit (sangrai medium). Hasil sangrai tampak di Gambar 1. Setelah itu kopi Gayo dan beras hasil sangrai digiling menggunakan mesin penggiling (home coffee grinder) dan diayak menggunakan mesin pengayak Meinzer II sieve shaker (CSC Scientific Company, Inc., Amerika Serikat) selama 10 menit dengan ukuran mesh No.40 untuk mendapatkan ukuran partikel yang seragam sebesar 420 mikrometer.
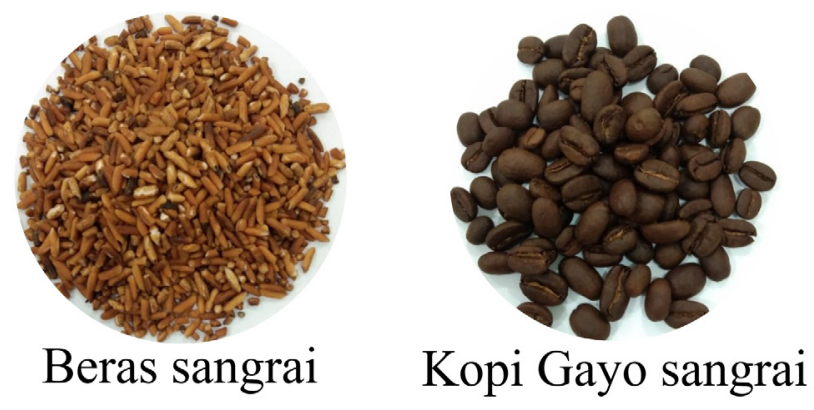

\section{Gambar 1. Sampel beras dan kopi Gayo yang telah disangrai}

Sebanyak 197 sampel disiapkan yang terdiri atas sampel kopi Gayo murni sebanyak 97 sampel dan kopi Gayo campuran sebanyak 100 sampel dengan berat masing-masing sampel adalah $1 \mathrm{~g}$. Sampel kopi Gayo campuran merupakan sampel kopi Gayo yang dicampur dengan beras sangrai dengan persentase campuran $10-50 \%(w / w)$. Seluruh sampel kemudian diekstraksi menggunakan air distilasi bersuhu $90-98{ }^{\circ} \mathrm{C}$. Untuk pengembangan model kalibrasi PLS maka sampel dibagi ke dalam tiga kelompok secara acak yaitu sampel kalibrasi (untuk membangun model), sampel validasi (untuk memvalidasi model) dan sampel prediksi (untuk menguji model). Karakteristik sampel kalibrasi, validasi dan prediksi dapat dilihat di Tabel 1. 
Tabel 1. Karakteristik sampel kopi Gayo murni dan campuran yang digunakan dalam penelitian.

\begin{tabular}{lccc}
\hline Item & Kalibrasi & Validasi & Prediksi \\
\hline Jumlah sampel & 104 & 62 & 31 \\
Rentang nilai & $0-50 \%$ & $0-50 \%$ & $0-50 \%$ \\
Rata-rata & $15,87 \%$ & $14,52 \%$ & $14,52 \%$ \\
Standar deviasi & $18,25 \%$ & $18,08 \%$ & $18,23 \%$ \\
\hline
\end{tabular}

\section{Proses Ekstraksi Sampel}

Proses ekstraksi sampel kopi dilakukan menggunakan air distilasi bersuhu $90-98{ }^{\circ} \mathrm{C}$ sesuai dengan prosedur yang digunakan oleh penelitian sebelumnya (Suhandy \& Yulia 2017b; Souto dkk., 2015).

\section{Pengambilan Spektra Sampel}

Data spektra sampel kopi Gayo murni dan kopi Gayo campuran diambil menggunakan spektrofotometer UVvisible (Genesys ${ }^{\mathrm{TM}}$ 10S UV-Vis, Thermo Scientific, USA) pada panjang gelombang 200-400 nm dengan interval $1 \mathrm{~nm}$. Spektrofotometer ini menggunakan lampu Xenon sebagai sumber cahaya dan dual silicon photodiodes sebagai detektor.

Pengukuran data spektra dilakukan dengan meneteskan $3 \mathrm{~mL}$ sampel ke dalam kuvet kuarsa ukuran $10 \mathrm{~mm}$. Untuk referensi digunakan air distilasi yang juga diteteskan sebanyak $3 \mathrm{~mL}$ ke dalam kuvet kuarsa ukuran $10 \mathrm{~mm}$. Spektrofotometer ini merupakan spektrofotometer dual-beam di mana spektra sampel diperoleh dengan mengukur intensitas cahaya yang melewati kuvet sampel dan kuvet referensi secara sekaligus pada mode pengukuran transmitans. Absorbans sampel kemudian dihitung dengan menggunakan negatif logaritmik (basis 10) terhadap rasio antara intensitas cahaya sampel dan referensi.

\section{Analisis Data Spektra dan Kemometrika}

Analisis data spektra meliputi proses perbaikan data spektra yaitu dengan melakukan transformasi spektra original menjadi spektra transformasi dengan menggunakan 3 buah algoritma yaitu: moving average 5-point (MAV), standard normal variate (SNV) dan Savitzky-Golay $1^{\text {st }}$ derivative 11 point $2^{\text {nd }}$ polynomial order (SG 1d). Algoritma MAV digunakan untuk menghilangkan noise dan meningkatkan signal-to-noise ratio (SNR). SNV dan SG 1d biasanya digunakan untuk menghilangkan efek hamburan dan perbedaan baseline spektra (Cunha dkk., 2017).

Untuk kemometrika, pada penelitian digunakan dua buah metode kemometrika yaitu principal components analysis (PCA) atau analisis komponen utama (AKU) dan partial least square regression (PLSR) atau regresi PLS. PCA merupakan metode klasifikasi tidak terbimbing yang dihitung menggunakan seluruh sampel (197 sampel) dengan metode validasi full-cross. PCA menghasilkan beberapa plot penting misalnya plot nilai skor untuk klusterisasi sampel dan $x$-loadings untuk investigasi kontribusi setiap panjang gelombang dalam proses klusterisasi sampel. PCA juga memungkinkan kita melakukan identifikasi sampel pencilan atau outlier yaitu dengan membuat plot Hotelling's $T^{2}$ versus Q-residual (Rodriguez dkk., 2019).

Sampel kalibrasi digunakan untuk membangun model kalibrasi PLS yang dihitung menggunakan algoritma PLS1 (PLS dengan satu peubah respon). Evaluasi model kalibrasi PLS dilakukan dengan menggunakan metode validasi $t$-test yaitu validasi dengan menggunakan sampel eksternal yang tidak digunakan dalam membangun model kalibrasi PLS yang dikenal sebagai sampel validasi. Parameter yang digunakan untuk menilai kualitas model kalibrasi PLS yang dibangun adalah: koefisien determinasi baik untuk kalibrasi maupun validasi $\left(R_{c a l}^{2}\right.$ dan $\left.R_{\text {val }}^{2}\right)$, standard error of calibration (SEC), standard error of validation (SEV). Kemudian model kalibrasi PLS juga dievaluasi berdasarkan parameter RPD (ratio prediction to deviation) dan RER (range error ratio). Model kalibrasi PLS yang baik adalah model yang memiliki nilai koefisien determinasi tinggi (lebih dari 0,90) dan nilai error (SEC dan SEV) rendah. Model kalibrasi PLS yang baik juga memiliki nilai RPD dan RER bernilai di atas 3 dan 10 . Untuk tahap validasi model, $\mathrm{RPD}_{v}$ dan $\mathrm{RER}_{v}$ dapat dihitung menggunakan Persamaan 1 dan 2 (Fearn, 2002; Williams, 2007; Williams, 2010).

$\mathrm{RPD}_{\mathrm{v}}=\frac{\mathrm{SD}_{\mathrm{v}}}{\mathrm{SEV}}$

$\mathrm{RER}_{\mathrm{v}}=\frac{(\text { maksimum-minimum })_{\mathrm{V}}}{\mathrm{SEV}}$

Di mana $\mathrm{RPD}_{\mathrm{v}}$ dan $\mathrm{RER}_{\mathrm{v}}$ merupakan nilai RPD dan RER di tahap validasi model, $\mathrm{SD}_{v}$ merupakan nilai standar deviasi sampel set untuk validasi dan (maksimum-minimum)v merupakan nilai selisih antara nilai maksimum dan minimum sampel set validasi.

Model kalibrasi PLS terbaik kemudian dipilih dan diuji kinerjanya dalam menghitung persentase campuran beras dalam kopi Gayo pada sampel prediksi dan hasil prediksinya dievaluasi berdasarkan parameter berikut: koefisien determinasi $\left(R_{\text {pred }}^{2}\right)$, standard error of prediction (SEP) dan bias. Nilai RPD dan RER untuk prediksi 
(RPDp dan RERP) juga dihitung dengan menggunakan persamaan 1 dan 2 dengan menggunakan data standar deviasi, maksimum dan minimum sampel. Prediksi yang baik memiliki nilai koefisien determinasi tinggi (lebih dari 0,90), nilai error (SEP dan bias) rendah dan RPDP dan RERp lebih dari 3 dan 10 (Fearn, 2002; Williams, 2007; Suhandy dkk., 2013; Nolasco-Perez dkk., 2019).

\section{Perangkat Lunak Pengolah Data}

Seluruh perhitungan analisis spektra seperti proses transformasi spektra dan seluruh analisis kemometrika seperti PCA dan regresi PLS menggunakan perangkat lunak The Unscrambler $X$ versi 10.4 (64-bit) (Camo Software AS, Oslo, Norway). Ini merupakan perangkat lunak yang popular dan digunakan secara luas untuk proses analisis data spektra.

\section{HASIL DAN PEMBAHASAN}

\section{Analisis Spektra Sampel Kopi di Daerah UV}

Gambar 2 dan 3 merupakan plot spektra original dan spektra transformasi rata-rata hasil pengukuran menggunakan spektrofotometer UV-Vis di daerah panjang gelombang 200-400 nm. Dari Gambar 2, intensitas absorbans paling tinggi adalah spektra dengan persentase campuran $0 \%$ atau kopi Gayo murni. Spektra untuk sampel dengan campuran paling besar yaitu $50 \%$ memiliki intensitas absorbans paling kecil. Secara umum, dapat dikatakan bahwa penurunan intensitas absorbans terjadi seiring dengan adanya peningkatan persentase kandungan campuran dalam kopi Gayo yaitu persentase beras. Semakin tinggi kandungan campurannya atau semakin tidak murni kopi Gayo maka intensitas absorbans-nya semakin kecil. Gambar 2 juga menunjukkan adanya intensitas absorbans sangat tinggi terjadi di interval 200-250 $\mathrm{nm}$ dengan absorbans sekitar 1 sampai 2,5. Mode transmitans digunakan dalam penelitian ini, sehingga intensitas cahaya yang diteruskan oleh sampel ke detektor dengan absorbans sebesar 1 sampai 2,5 adalah sebesar $10 \%$ sampai $0,3162 \%$ saja. Artinya, sebagian besar gelombang elektromagnetik yang ada kemudian diserap oleh sampel di interval 200-250 nm. Atas dasar inilah, interval $250-400 \mathrm{~nm}$ saja yang diambil untuk analisis berikutnya. Menurut beberapa referensi, spektra sampel kopi di panjang gelombang 250-400 $\mathrm{nm}$ berkorelasi dengan transisi elektronik tipe $n \rightarrow \Pi^{*}$ (transisi elektronik dari $\mathrm{n}$ atau garis orbit non-bonding ke phi star atau garis orbit antibonding) dari kromofor ikatan $\mathrm{C}=\mathrm{O}$ yang terdapat pada senyawa trigonelina (trigonelline), kafein (caffeine), asam kafeat (caffeic acid) dan melanoidin (Fujioka \& Shibamoto, 2008;
Moreira dkk., 2012; Souto dkk., 2015). Dari Gambar 3 , perbedaan spektra sebagai respon atas perbedaan persentase campuran lebih spesifik terjadi di beberapa puncak panjang gelombang seperti panjang gelombang $270 \mathrm{~nm}, 290 \mathrm{~nm}, 310 \mathrm{~nm}$ dan $340 \mathrm{~nm}$.

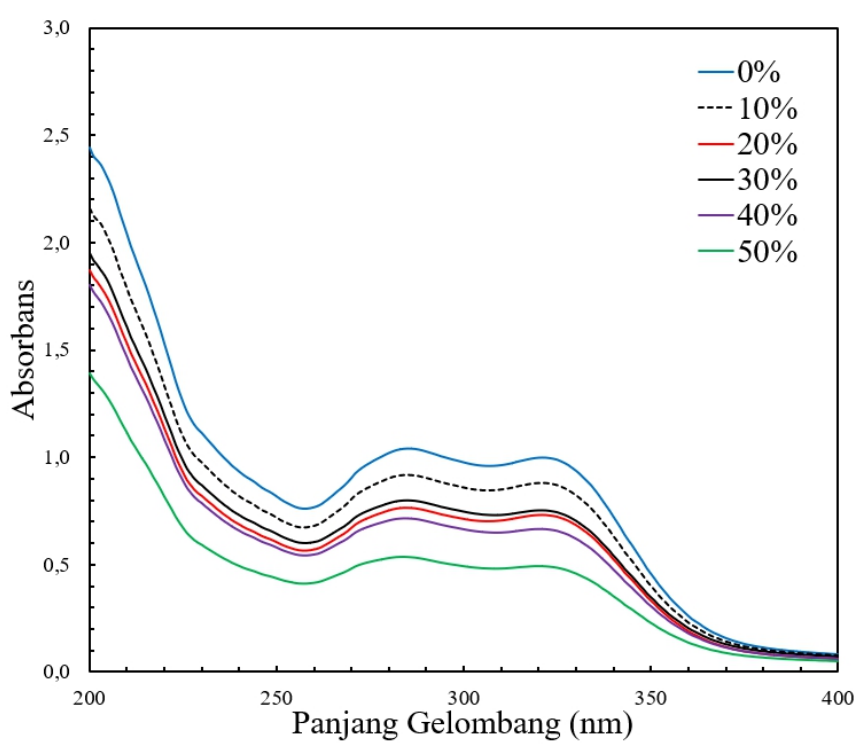

Gambar 2. Spektra original rataan sampel kopi Gayo dengan persentase campuran yang berbeda pada panjang gelombang 200-400 nm

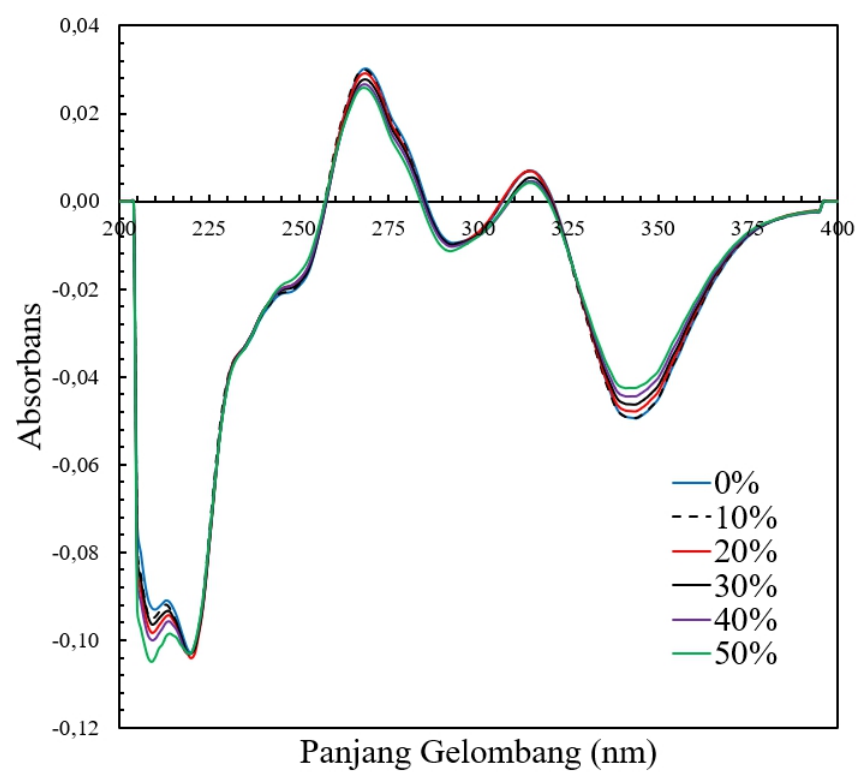

Gambar 3. Spektra transformasi rataan sampel kopi Gayo dengan persentase campuran yang berbeda pada panjang gelombang $200-400 \mathrm{~nm}$

Hasil pengambilan spektra yang dipresentasikan di Gambar 2 dan 3 menunjukkan bahwa panjang 
gelombang di interval $200-250 \mathrm{~nm}$ dengan intensitas absorbans sangat tinggi tidak dilibatkan dalam analisis berikutnya. Salah satu alasan tingginya intensitas absorbans di interval 200-250 nm adalah terkait karakteristik lampu Xenon yang digunakan di dalam penelitian ini. Seperti dilaporkan oleh Luksiene dkk. (2007), intensitas gelombang elektromagnetik lampu Xenon di sekitar panjang gelombang 200-250 nm tidak terlalu tinggi (lemah).

Puncak panjang gelombang yang teridentifikasi di panjang gelombang $270 \mathrm{~nm}, 290 \mathrm{~nm}, 310 \mathrm{~nm}$, dan 340 $\mathrm{nm}$ sejalan dengan hasil penelitian sebelumnya. Spektra UV yang diperoleh oleh Dankowska dkk. (2017) untuk kopi bubuk arabika dan robusta asal berbagai negara (Brasil, India, Indonesia, dan lainnya) juga memperoleh beberapa puncak panjang gelombang di $275 \mathrm{~nm}, 290$ $\mathrm{nm}$, dan $320 \mathrm{~nm}$. Lebih lanjut, panjang gelombang tersebut berhubungan dengan absorbans senyawa yang terkandung dalam kopi. Panjang gelombang $270 \mathrm{~nm}$ dekat dengan absorbans maksimum senyawa kafeina (caffeine) pada panjang gelombang $275 \mathrm{~nm}$. Panjang gelombang $290 \mathrm{~nm}$ dan $310 \mathrm{~nm}$ sangat dekat dengan absorbans maksimum dari senyawa asam klorogenat (chlorogenic acids) dan trigonelina (trigonelline) (Dankowska dkk., 2017). Penelitian sebelumnya menggunakan spektroskopi UV-visible melaporkan puncak panjang gelombang di $320 \mathrm{~nm}$ yang kemudian bergeser ke panjang gelombang $325 \mathrm{~nm}$ dan berkorelasi dengan asam kafeat (caffeic acid) (Souto dkk., 2015).

\section{Hasil Analisis Komponen Utama (AKU)}

Analisis komponen utama (AKU) dihitung menggunakan seluruh sampel (197 sampel) dengan data spektra transformasi dengan interval $250-400 \mathrm{~nm}$ sebagai peubah $x$. Metode validasi yang digunakan adalah metode full-cross validation. Gambar 4 merupakan salah satu hasil analisis komponen utama dalam bentuk plot Hotelling's $T^{2}$ di sumbu $x$ dan $Q$-residual di sumbu $y$ untuk komponen utama pertama atau first principal component (KU1 atau PC1) Kedua parameter tersebut biasanya digunakan untuk mengevaluasi ada tidaknya sampel pencilan atau outlier di dalam data set yang digunakan untuk membangun model. Sebuah sampel dikatakan sebagai kandidat pencilan jika saat yang bersamaan memiliki nilai Hotelling's $T^{2}$ dan $Q$-residual lebih besar dari ambang batas atau threshold (melewati garis merah putus-putus). Dari Gambar 4, garis merah putus-putus menunjukkan garis dengan tingkat kepercayaan $95 \%$ dan merupakan ambang batas yang ditetapkan untuk Hotelling's $T^{2}$ dan $Q$-residual. Tampak bahwa sebagian besar sampel berada di dalam ambang batas dan hanya terdapat 7 sampel (ditandai dengan persegi panjang hitam) berada di luar garis merah. Berdasarkan hasil ini maka 7 sampel yang berada di luar garis merah tersebut dianggap sebagai sampel pencilan (outlier) yaitu yang terdiri atas 6 sampel kalibrasi dan 1 sampel prediksi.

Plot berikutnya yang penting dari hasil analisis komponen utama adalah plot dua dimensi untuk nilai skor dua komponen utama pertama (PC1 versus PC2) atau plot tiga dimensi untuk nilai skor tiga komponen utama pertama (PC1xPC2xPC3). Gambar 5 adalah plot dua dimensi (PC1xPC2) dan Gambar 6 merupakan plot tiga dimensi (PC1xPC2xPC3). PC1 menjelaskan variasi data awal sebanyak $88 \%$ sedangkan PC2 dan PC3 mampu menjelaskan variasi data awal masing-masing sebanyak 5\%. Sebagian besar sampel kopi Gayo murni terletak sebelah kiri PC1 $(\mathrm{PC} 1<0)$ sedangkan sebagian

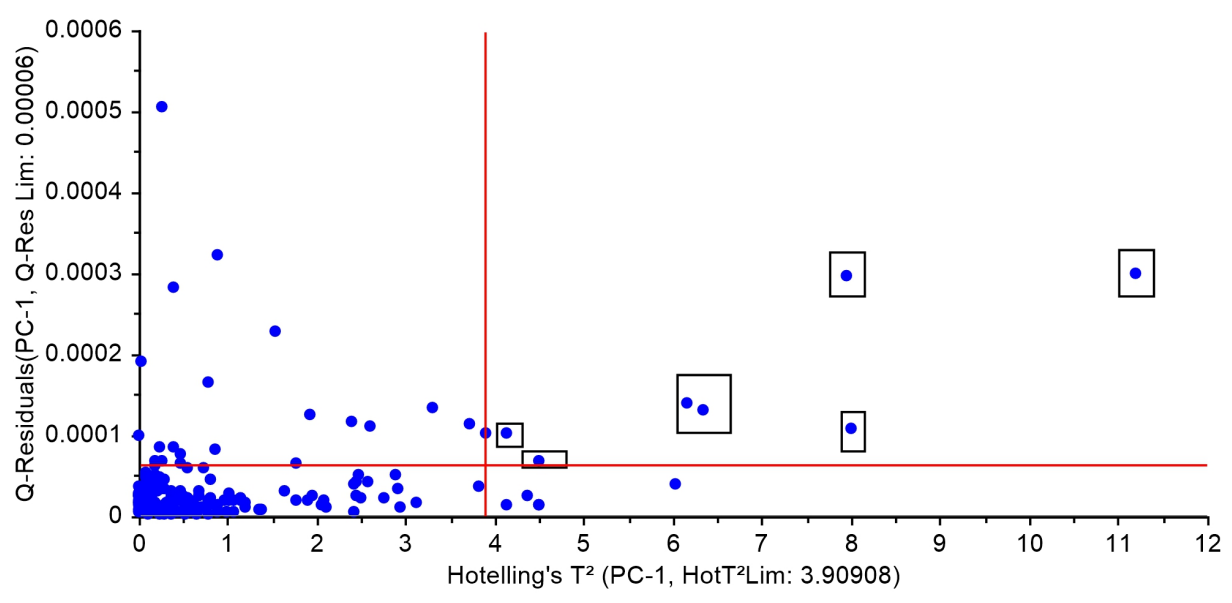

Gambar 4. Plot Hotelling's $T^{2}$ versus Q-residual hasil perhitungan analisis komponen utama sampel kopi Gayo pada spektra transformasi dan interval panjang gelombang 250-400 nm 
besar sampel kopi Gayo campuran terletak di sebelah kanan PC1 (PC1 $>0)$. Dari sini jelas terlihat adanya potensi pemisahan dua kelompok sampel yaitu sampel kopi Gayo murni dan sampel kopi Gayo yang telah dicampur beras (10-50\%).

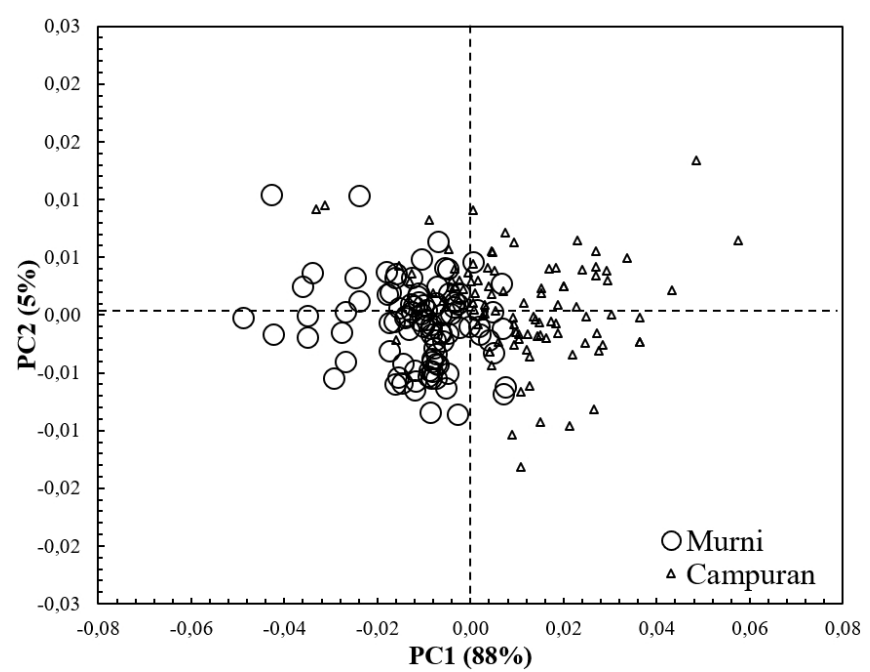

Gambar 5. Plot dua dimensi nilai skor PC1 dan PC2 hasil analisis komponen utama sampel kopi Gayo pada spektra transformasi dan interval panjang gelombang 250-400 nm

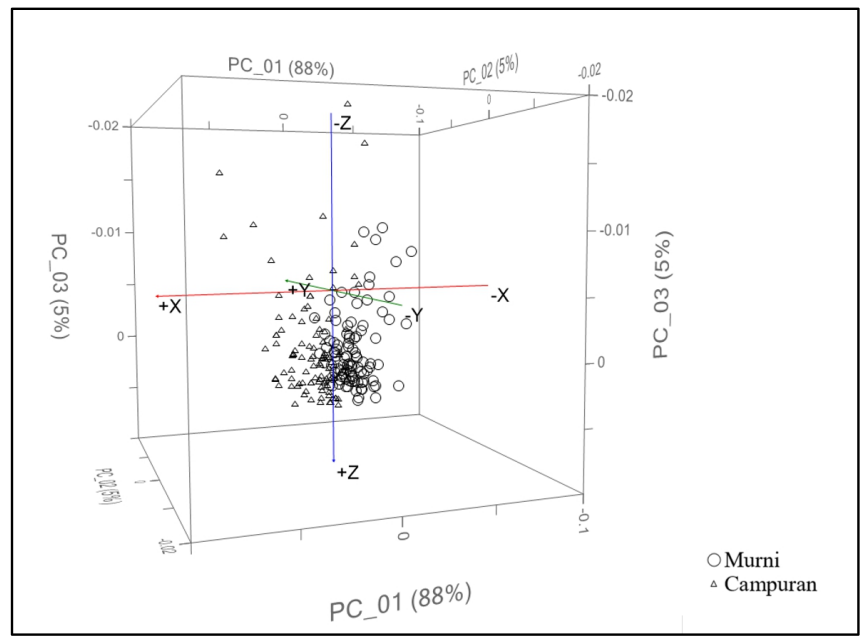

Gambar 6. Plot tiga dimensi nilai skor PC1, PC2, dan PC3 hasil analisis komponen utama sampel kopi Gayo pada spektra transformasi di interval panjang gelombang 250-400 nm

Plot lain yang sangat penting dari hasil analisis komponen utama adalah plot $x$-loadings yaitu plot untuk panjang gelombang di sumbu $x$ dan nilai $x$-loadings di sumbu $y$ seperti ditunjukkan di Gambar 7. Plot ini menunjukkan panjang gelombang mana saja yang memiliki nilai $x$-loadings besar. Panjang gelombang dengan nilai $x$-loadings besar berarti sangat penting dengan kontribusi besar terhadap proses pemisahan antara kluster kopi Gayo murni dan kopi Gayo campuran. Hasil penelitian menunjukkan beberapa panjang gelombang memiliki nilai $x$-loadings tinggi seperti pada panjang gelombang $260 \mathrm{~nm}, 270 \mathrm{~nm}, 285 \mathrm{~nm}, 310 \mathrm{~nm}$, $330 \mathrm{~nm}$ dan $345 \mathrm{~nm}$.

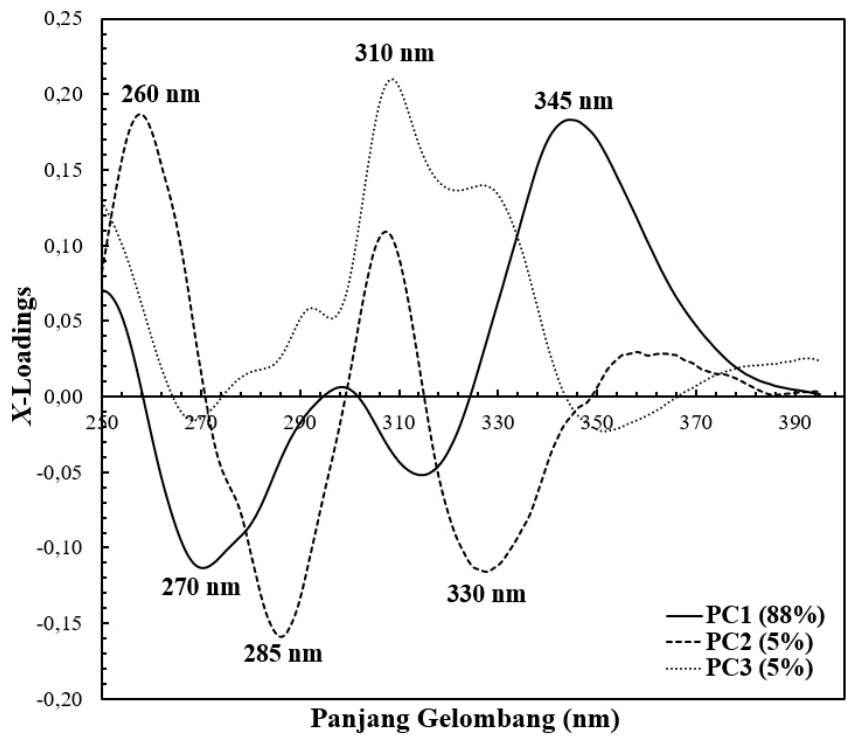

Gambar 7. Plot panjang gelombang dan nilai $x$-loadings hasil analisis komponen utama sampel kopi Gayo pada spektra transformasi di interval panjang gelombang $250-400 \mathrm{~nm}$

Hasil analisis komponen utama atau PCA menunjukkan kemampuan PCA untuk mengelompokkan sampel kopi ke dalam dua kluster yaitu kluster kopi Gayo murni dan kopi Gayo campuran. Beberapa panjang gelombang yang berkontribusi dalam proses pemisahan kopi murni dan kopi campuran berdasarkan hasil analisis PCA adalah 260, 270, 285, 310, 330, dan $345 \mathrm{~nm}$. Beberapa panjang gelombang tersebut juga berkorelasi dengan absorbans senyawa penting di dalam kopi. Penelitian sebelumnya juga menunjukkan efektivitas PCA untuk proses klusterisasi sampel. Suhandy \& Yulia (2017b) menggunakan PCA untuk mengklusterisasi sampel kopi bubuk lanang dan kopi biasa serta melaporkan panjang gelombang dengan $x$-loading tinggi di panjang gelombang 230, 250, 270, 310 , dan $350 \mathrm{~nm}$. Hasil ini menunjukkan bahwa hasil pengambilan spektra yang dilakukan di penelitian ini merupakan hasil pengambilan spektra terpercaya dan sejalan dengan penelitian sebelumnya. 


\section{Hasil Pengembangan Model Kalibrasi PLS}

Model kalibrasi PLS untuk penentuan persentase beras (campuran) pada kopi Gayo dibangun menggunakan algoritma regresi PLS1 (PLS dengan satu peubah respon) menggunakan sampel kalibrasi dan divalidasi menggunakan sampel validasi dengan metode validasi $t$-test (menggunakan data awal seperti di Tabel 1). Model dibangun menggunakan dua tipe spektra yaitu spektra original dan spektra transformasi di beberapa interval panjang gelombang. Jumlah peubah laten atau latent variables (LV) yang terlibat di dalam model ditentukan menggunakan nilai parameter root mean square error of validation (RMSEV) terkecil. Hasil pengembangan model PLS dapat dilihat di Tabel 2.
Secara umum model kalibrasi PLS sangat dipengaruhi oleh tipe spektra yang digunakan dan interval panjang gelombang yang terlibat. Untuk tipe spektra original, kualitas model kalibrasi PLS semakin membaik dengan meningkatnya interval dengan interval terbaik diperoleh pada panjang gelombang 250-390 nm di mana nilai RPD dan RER terus meningkat dari 1,87 dan 5,18 untuk interval 250-300 nm menjadi 2,70 dan 7,46 untuk interval 250-390 nm. Untuk interval yang sama, model kalibrasi PLS untuk tipe spektra transformasi lebih baik dibandingkan dengan tipe spektra original, menunjukkan bahwa perbaikan kualitas spektra dengan menggunakan algoritma MAV, SNV dan SG 1d telah berhasil memperbaiki model kalibrasi PLS yang dibangun. Model terbaik diperoleh untuk tipe spektra

Tabel 2. Hasil pengembangan model kalibrasi PLS menggunakan seluruh sampel kalibrasi dan validasi (total sampel 166).

\begin{tabular}{cccccccccc}
\hline Tipe spektra & Interval & LV & $R_{\text {cal }}^{2}$ & $R_{\text {val }}^{2}$ & SEC & SEV & bias & RPD $_{v}$ & RER $_{v}$ \\
\hline Original & $250-300 \mathrm{~nm}$ & 6 & 0,87 & 0,72 & 6,69 & 9,65 & 0,32 & 1,87 & 5,18 \\
& $250-310 \mathrm{~nm}$ & 5 & 0,81 & 0,79 & 7,96 & 8,32 & 0,25 & 2,17 & 6,01 \\
& $250-320 \mathrm{~nm}$ & 4 & 0,79 & 0,77 & 8,33 & 8,69 & 0,50 & 2,08 & 5,75 \\
& $250-330 \mathrm{~nm}$ & 6 & 0,85 & 0,82 & 7,05 & 7,67 & $-0,50$ & 2,36 & 6,52 \\
& $250-340 \mathrm{~nm}$ & 7 & 0,85 & 0,82 & 6,96 & 7,57 & $-0,53$ & 2,39 & 6,61 \\
& $250-350 \mathrm{~nm}$ & 7 & 0,85 & 0,82 & 6,98 & 7,58 & $-0,34$ & 2,39 & 6,60 \\
& $250-360 \mathrm{~nm}$ & 7 & 0,86 & 0,83 & 6,94 & 7,52 & $-0,32$ & 2,40 & 6,65 \\
& $250-370 \mathrm{~nm}$ & 7 & 0,86 & 0,83 & 6,91 & 7,49 & $-0,36$ & 2,41 & 6,68 \\
& $250-380 \mathrm{~nm}$ & 7 & 0,86 & 0,83 & 6,75 & 7,48 & $-0,35$ & 2,42 & 6,68 \\
\hline Transformasi & $\mathbf{2 5 0 - 3 9 0 ~ n m}$ & $\mathbf{1 0}$ & $\mathbf{0 , 9 4}$ & $\mathbf{0 , 8 6}$ & $\mathbf{4 , 5 4}$ & $\mathbf{6 , 7 0}$ & $-\mathbf{0 , 1 6}$ & $\mathbf{2 , 7 0}$ & $\mathbf{7 , 4 6}$ \\
& $250-400 \mathrm{~nm}$ & 10 & 0,94 & 0,86 & 4,53 & 6,78 & $-0,06$ & 2,67 & 7,37 \\
\hline $250-300 \mathrm{~nm}$ & 6 & 0,88 & 0,86 & 6,24 & 6,82 & $-0,04$ & 2,65 & 7,33 \\
& $250-310 \mathrm{~nm}$ & 7 & 0,88 & 0,86 & 6,22 & 6,74 & $-0,10$ & 2,68 & 7,42 \\
& $250-320 \mathrm{~nm}$ & 7 & 0,90 & 0,87 & 5,82 & 6,42 & $-0,07$ & 2,82 & 7,79 \\
& $250-330 \mathrm{~nm}$ & 13 & 0,92 & 0,90 & 5,12 & 5,64 & 0,03 & 3,21 & 8,87 \\
& $250-340 \mathrm{~nm}$ & 13 & 0,92 & 0,91 & 5,03 & 5,29 & $-0,31$ & 3,55 & 9,45 \\
& $250-350 \mathrm{~nm}$ & 14 & 0,93 & 0,91 & 5,00 & 5,29 & $-0,12$ & 3,55 & 9,45 \\
& $250-360 \mathrm{~nm}$ & 8 & 0,91 & 0,92 & 5,33 & 5,14 & $-0,46$ & 3,52 & 9,73 \\
& $250-370 \mathrm{~nm}$ & 8 & 0,92 & 0,92 & 5,17 & 5,03 & $-0,33$ & 3,59 & 9,94 \\
& $250-380 \mathrm{~nm}$ & 8 & 0,92 & 0,93 & 5,04 & 4,91 & $-0,50$ & 3,68 & 10,18 \\
& $\mathbf{2 5 0} \mathbf{n m}$ & $\mathbf{8}$ & $\mathbf{0 , 9 2}$ & $\mathbf{0 , 9 3}$ & $\mathbf{5 , 0 3}$ & $\mathbf{4 , 8 9}$ & $\mathbf{- 0 , 5 0}$ & $\mathbf{3 , 7 0}$ & $\mathbf{1 0 , 2 2}$ \\
\hline & $\mathbf{2 5 0} \mathrm{nm}$ & $\mathbf{8}$ & 0,92 & 0,93 & 5,02 & 4,92 & $-0,54$ & 3,67 & 10,16 \\
\hline
\end{tabular}


transformasi dengan interval panjang gelombang 250$390 \mathrm{~nm}$. Model ini memiliki koefisien determinasi tinggi dan lebih dari $0,90\left(R_{c a l}^{2}=0,92\right.$ dan $\left.R_{\text {val }}^{2}=0,93\right)$. Model ini memiliki nilai SEV terkecil sebesar $4,89 \%$ yang menghasilkan nilai $\mathrm{RPD}_{\mathrm{v}}$ dan $\mathrm{RER}_{\mathrm{v}}$ terbesar yaitu 3,70 dan 10,22.

Untuk melihat pengaruh sampel pencilan terhadap model kalibrasi PLS maka 7 sampel pencilan yang terdiri atas 6 sampel kalibrasi dan 1 sampel prediksi seperti yang ditunjukkan oleh plot Hotelling's $T^{2}$ versus $Q$-residual di Gambar 4 dikeluarkan dari data set. Tabel 3 merupakan data set baru setelah mengeluarkan sampel pencilan.

Tabel 3. Karakteristik sampel kopi Gayo murni dan campuran yang digunakan dalam penelitian setelah sampel pencilan dikeluarkan dari data set

\begin{tabular}{lccc}
\hline \multicolumn{1}{c}{ Item } & Kalibrasi & Validasi & Prediksi \\
\hline Jumlah sampel & 98 & 62 & 30 \\
Rentang nilai & $0-50 \%$ & $0-50 \%$ & $0-50 \%$ \\
Rata-rata & $14,90 \%$ & $14,52 \%$ & $15,00 \%$ \\
Standar deviasi & $17,48 \%$ & $18,08 \%$ & $18,34 \%$ \\
\hline
\end{tabular}

Dengan menggunakan data set di Tabel 3, model kalibrasi PLS dibangun kembali untuk spektra original dan transformasi di interval 250-390 nm dan hasilnya ditunjukkan di Tabel 4. Kualitas model kalibrasi baik original maupun transformasi menjadi lebih baik dengan $\mathrm{RPD}_{\mathrm{v}}$ dan $\mathrm{RER}_{\mathrm{v}}$ meningkat sebesar $4,8 \%$ dan $5,1 \%$ untuk spektra original dan $4,6 \%$ dan $4,8 \%$ untuk spektra transformasi. Meskipun peningkatannya tidak terlalu tinggi tetapi hasil ini memperkuat justifikasi untuk mengeluarkan sampel pencilan tersebut dari data set sehingga model kalibrasi PLS yang dibangun menjadi lebih tangguh (robust).

\section{Hasil Prediksi Menggunakan Model Kalibrasi PLS Terbaik}

Model kalibrasi PLS terbaik hasil pengembangan dari data set setelah tidak melibatkan sampel pencilan kemudian digunakan untuk menghitung persentase beras pada sampel prediksi yang telah disiapkan yaitu sebanyak 30 sampel (sesuai data set di Tabel 3). Hasil perhitungan dipresentasikan dalam bentuk plot antara nilai persentase beras aktual dan prediksi seperti tampak di Gambar 8 yang menggunakan model kalibrasi PLS spektra original dengan interval 250-390 nm dan di Gambar 9 yang menggunakan model kalibrasi PLS spektra transformasi dengan interval 250-390 nm. Hasil prediksi menggunakan spektra original memiliki koefisien determinasi sebesar $0,80, \mathrm{SEP}=8,03 \%$ dan bias $=1,64 \%$. Sedangkan untuk model spektra transformasi menghasilkan prediksi dengan koefisien determinasi $0,90, \mathrm{SEP}=5,86 \%$ dan bias $=-0,20 \%$. Sehingga secara umum hasil prediksi menggunakan spektra transformasi dengan interval 250-390 nm lebih baik dibandingkan spektra original dengan interval yang sama.

Dengan menggunakan data set di Tabel 3 maka diperoleh standar deviasi untuk sampel prediksi $\left(\mathrm{SD}_{\mathrm{p}}\right)$ adalah $18,34 \%$ dan nilai maksimum-minimum adalah $50 \%$. Sehingga dengan menggunakan persamaan 1 dan 2 kita juga dapat menghitung nilai RPD dan RER untuk prediksi yaitu $\mathrm{RPD}_{\mathrm{p}}=2,28$ dan $\mathrm{RER}_{\mathrm{p}}=6,23$ untuk spektra original dan $\operatorname{RPD}_{\mathrm{p}}^{\mathrm{p}}=3,13$ dan $\operatorname{RER}_{\mathrm{p}}=8,53$ untuk spektra transformasi.

Pengembangan model kalibrasi PLS menunjukkan spektra transformasi dengan interval 250-390 nm menghasilkan model kalibrasi PLS terbaik dengan $R P D=3,70$ dan $R E R=10,22$. Hasil ini memperlihatkan pentingnya proses perbaikan data spektra dan pemilihan interval panjang gelombang di saat pengembangan model kalibrasi PLS. Penelitian sebelumnya juga menunjukkan hal ini. Suhandy \& Yulia (2017a) membangun model kalibrasi PLS untuk penentuan kandungan kopi bubuk luwak menggunakan spektra original dan beberapa spektra transformasi. Spektra transformasi dengan algoritma Savitzky-Golay smoothing menghasilkan model kalibrasi PLS terbaik dengan RPD sebesar 4,64. Di dalam penelitian kali ini, tidak hanya pemilihan tipe spektra dan interval panjang gelombang yang penting, ternyata pemilihan sampel juga terbukti penting dalam membangun model yang tangguh. Dengan bantuan plot Hotelling's $T^{2}$ versus $Q$-residual, beberapa sampel teridentifikasi sebagai sampel pencilan. Pengembangan model kalibrasi PLS dengan sampel terpilih yaitu tanpa melibatkan sampel

Tabel 4. Hasil pengembangan model kalibrasi PLS menggunakan sampel kalibrasi dan validasi setelah dikurangi sampel pencilan (total sampel 160)

\begin{tabular}{cccccccccc}
\hline Tipe spektra & Interval & $\mathrm{LV}$ & $R_{\text {cal }}^{2}$ & $R_{\text {val }}^{2}$ & SEC & SEV & bias & RPD $_{v}$ & RER $_{v}$ \\
\hline Original & $250-390 \mathrm{~nm}$ & 9 & 0,92 & 0,88 & 4,88 & 6,38 & 0,05 & 2,83 & 7,84 \\
Transformasi & $250-390 \mathrm{~nm}$ & 8 & 0,93 & 0,93 & 4,74 & 4.67 & $-0,43$ & 3,87 & 10,71 \\
\hline
\end{tabular}




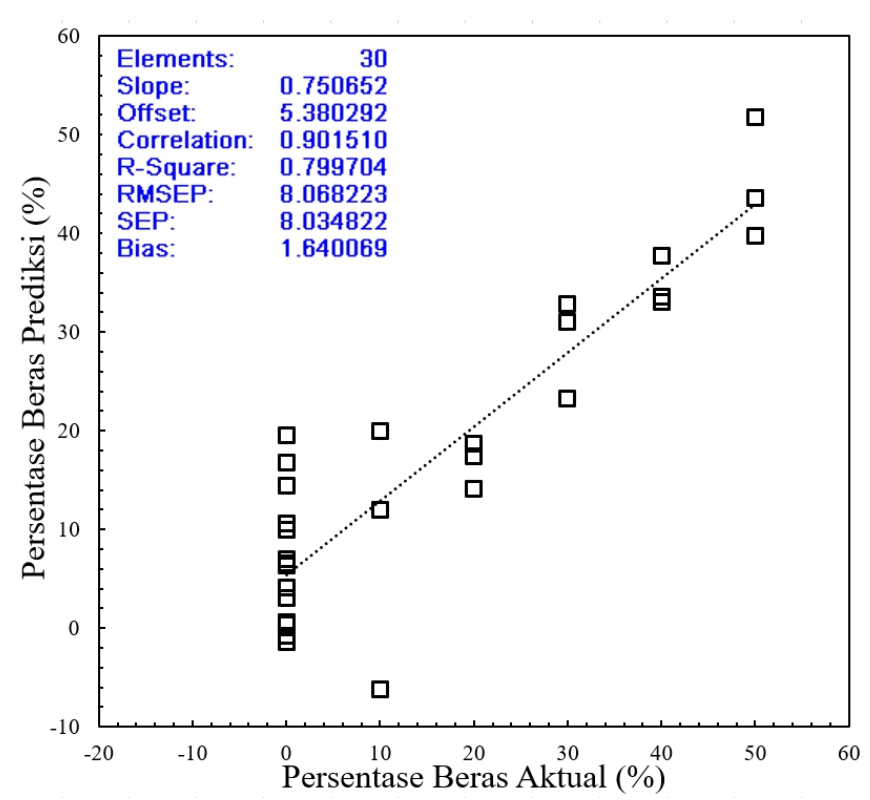

Gambar 8. Plot persentase beras aktual dan prediksi hasil prediksi menggunakan model kalibrasi PLS spektra original dengan interval $250-390 \mathrm{~nm}$

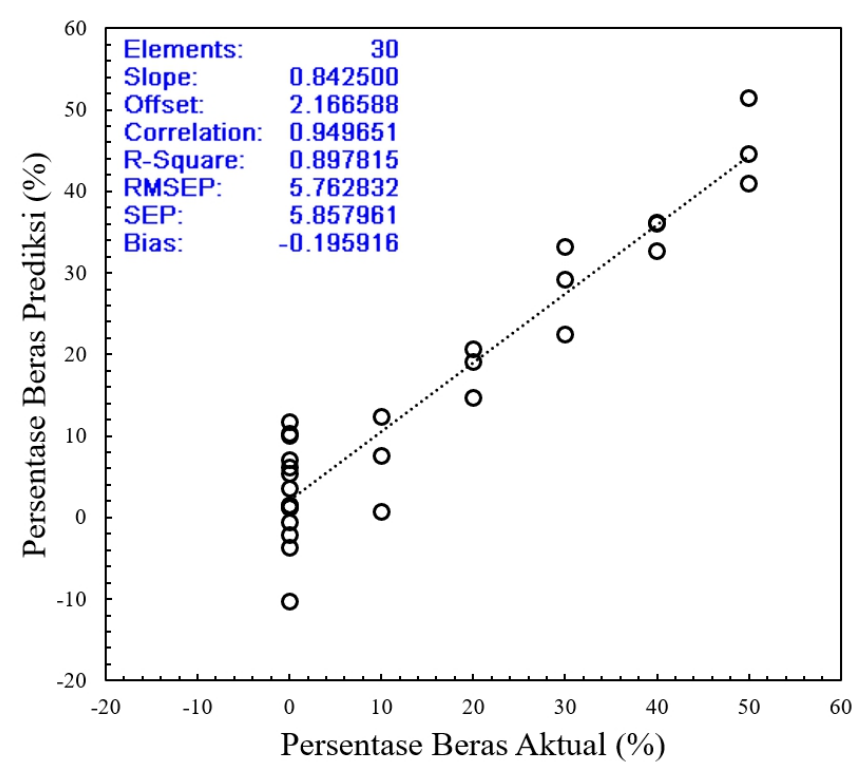

Gambar 9. Plot persentase beras aktual dan prediksi hasil prediksi menggunakan model kalibrasi PLS spektra transformasi dengan interval 250-390 nm

pencilan mampu memperbaiki kualitas model kalibrasi PLS. RPD dan RER pada interval $250-390 \mathrm{~nm}$ meningkat sebesar $4,8 \%$ dan $5,1 \%$ untuk spektra original dan $4,6 \%$ dan $4,8 \%$ spektra untuk transformasi. Model kalibrasi terbaik yang dibangun dengan tipe spektra transformasi interval 250-390 nm dan sampel terpilih memiliki $R_{\text {cal }}^{2}=0,93, R_{\text {val }}^{2}=0,93$, RPD dan RER sebesar
3,87 dan 10,71. Model ini dengan RPD $>3$ dan RER > 10 , memenuhi syarat sebagai model kalibrasi PLS yang dapat digunakan untuk prediksi persentase beras pada sampel kopi bubuk Gayo yang dicampur beras. Hasil ini memang masih inferior dibandingkan dengan hasil yang diperoleh oleh Winkler-Moser dkk. (2015) yang membangun model kalibrasi PLS untuk memprediksi jagung yang dicampurkan ke dalam kopi bubuk arabika Brasil dengan model memiliki $R^{2}$ sebesar 0,979 dan 0,974 untuk kalibrasi dan validasi. Pizarro dkk. (2007) membangun model kalibrasi PLS menggunakan data spektra NIR untuk menghitung persentase kopi bubuk robusta dalam campuran kopi bubuk arabika-robusta dengan $R^{2}=0,993 \sim 1,000$.

Nilai bias yang diperoleh di dalam penelitian ini sebesar $0,05 \%$ dan $0,43 \%$ (Tabel 4) tidak jauh berbeda dengan nilai bias yang diperoleh oleh Ebrahimi-Najafabadi dkk. (2012) (bias= 0,53\%) yang membangun model kalibrasi PLS dengan data spektra NIR untuk menghitung kandungan jelai (barley) yang dicampurkan ke dalam kopi bubuk.

Hasil prediksi terbaik pada penelitian ini diperoleh menggunakan model kalibrasi PLS spektra transformasi dengan interval 250-390 nm dengan sampel terpilih. RPD dan RER yang diperoleh saat prediksi sampel adalah 3,13 dan 8,53. Nilai bias dan SEP yang diperoleh adalah sebesar $-0,20 \%$ dan $5,86 \%$. Di penelitian sebelumnya prediksi kandungan jagung menggunakan model kalibrasi PLS menghasilkan bias sebesar -0,58\% (Ebrahimi-Najafabadi dkk., 2012).

Dari pembahasan ini maka dapat dikatakan bahwa persentase beras dalam campuran kopi arabika Gayo dapat diprediksi menggunakan spektroskopi UV dengan hasil yang dapat diterima. Hasil pengukuran masih inferior dibandingkan dengan pengukuran berbasis spektroskopi NIR misalnya. Hanya saja, dengan perbedaan yang tidak terlalu jauh dari sisi akurasi, penggunaan spektroskopi UV untuk deteksi dan prediksi pencampuran kopi bubuk Gayo oleh beras sangat layak dihilirisasi dengan pertimbangan keterjangkauan harga alat spektrofotometer UV. Ke depan, spektroskopi UV sangat potensial digunakan sebagai metode analisis pada sistem uji keaslian kopi Gayo sebagai salah satu kopi spesialti andalan bangsa.

\section{KESIMPULAN}

Persentase beras yang dicampurkan ke dalam kopi bubuk arabika Gayo dapat diprediksi dengan baik menggunakan spektroskopi UV. Selain itu penelitian yang dilaksanakan juga menegaskan pentingnya perbaikan spektra yaitu penggunaan spektra transformasi, pemilihan interval panjang gelombang dan 
pentingnya pemilihan sampel dengan deteksi sampel pencilan. Sehingga ke depan untuk pengembangan model kalibrasi PLS menggunakan data spektra UV harus memperhatikan tiga hal tersebut yaitu pemilihan algoritma perbaikan data spektra, pemilihan interval panjang gelombang yang terlibat dan pemilihan sampel dengan memastikan tidak melibatkan sampel pencilan. Penelitian yang dilakukan dapat memberi jalan bagi terbangunnya sistem uji keaslian kopi spesialti Indonesia dengan harga spektrofotometer yang lebih terjangkau sehingga mudah dalam proses hilirisasinya. Hanya saja, pada prakteknya pengoplosan kopi di Indonesia seringkali melibatkan beberapa bahan pengoplos yang dicampurkan secara sekaligus pada kopi. Untuk itu ke depan perlu diinvestigasi kuantifikasi pengoplosan dengan variasi beberapa bahan pengoplos seperti jagung, kedelai dan lain sebagainya. Model kalibrasi PLS untuk penentuan bahan pengoplos lebih dari satu bisa menggunakan algoritma PLS2 yaitu regresi PLS dengan lebih dari 2 peubah respon.

\section{UCAPAN TERIMA KASIH}

Penulis menyampaikan ucapan terima kasih kepada Kementerian Riset dan Teknologi, Badan Riset dan Inovasi Nasional (BRIN) Republik Indonesia atas bantuan pendanaan penelitian ini melalui hibah penelitian PKPT 2020-2022.

\section{KONFLIK KEPENTINGAN}

Tidak ada konflik kepentingan pada penelitian ini.

\section{DAFTAR PUSTAKA}

Aboulwafa, M.M., Youssef, F.S., Gad, H.A., Sarker, S.D., Nahar, L., Al-Azizi, M.M., \& Ashour, M.L. (2019). Authentication and discrimination of green tea samples using UV-Visible, FTIR and HPLC techniques coupled with chemometrics analysis. Journal of Pharmaceutical and Biomedical Analysis, 164: 653-658. https://doi.org/10.1016/j. jpba.2018.11.036.

Bansal, S., Singh, A., Mangal, M., Mangal, A.K., \& Kumar, S. (2017). Food adulteration: sources, health risks, and detection methods. Critical Reviews in Food Science and Nutrition, 57(6): 1174-1189. https:// doi.org/10.1080/10408398.2014.967834.

Briandet, R., Kemsley, E.K., \& Wilson, R.H. (1996). Approachestoadulterationdetectionininstantcoffees using infrared spectroscopy and chemometrics. Journal of The Science of Food and Agriculture, 71(3):359-366.https://doi.org/10.1002/ (SICI)1097-0010(199607)71:3\%3C359:AIDJSFA593\%3E3.0.CO;2-D.

Cunha, C.L., Luna, A.S., Oliveira, R.C.G., Xavier, G.M., Paredes, M.L.L., \& Torres, A.R. (2017). Predicting the properties of biodiesel and its blends using midFT-IR spectroscopy and first-order multivariate calibration. Fuel, 204: 185-194. https://doi. org/10.1016/j.fuel.2017.05.057.

Dankowska, A., Domagała, A., \& Kowalewski, W. (2017). Quantification of coffea arabica and coffea canephora var. robusta concentration in blends by means of synchronous fluorescence and UV-vis spectroscopies. Talanta, 172: 215-220. https:// doi.org/10.1016/j.talanta.2017.05.036.

DGIP. (2020). Buku Persyaratan Indikasi Geografis. http://e-book.dgip.go.id/indikasigeografis/?book=kopi-arabika-gayo. [1 Mei 2020].

dos Santos, C.A.T., Páscoa, R.N., Porto, P.A., Cerdeira, A.L., González-Sáiz, J.M., Pizarro, C., \& Lopes, J.A. (2018). Raman spectroscopy for wine analyses: a comparison with near and mid infrared spectroscopy. Talanta, 186: 306-314. https://doi. org/10.1016/j.talanta.2018.04.075.

Ebrahimi-Najafabadi, H., Leardi, R., Oliveri, P., Chiara Casolino, M., Jalali-Heravi, M., \& Lanteri, S. (2012). Detection of addition of barley to coffee using near infrared spectroscopy and chemometric techniques. Talanta, 99: 175-179. https://doi. org/10.1016/j.talanta.2012.05.036.

Fearn, T. (2002). Assessing calibrations: SEP, RPD, RER and R2. NIR News, 13(6): 12-13. https:// doi:10.1255/nirn.689.

Fujioka, K., \& Shibamoto, T. (2008). Chlorogenic acid and caffeine contents in various commercial brewed coffees. Food Chemistry, 106(1): 217-221. https://doi:10.1016/j.foodchem.2007.05.091.

Garcia, L.M.Z., Pauli, E.D., Cristiano, V., Camara, C.A.P., Scarminio, I.S., \& Nixdorf, S.L. (2009). Chemometric evaluation of adulteration profile in coffee due to corn and husk by determining carbohydrates using HPAEC-PAD. Journal of Chromatographic Science, 47: 825-832. https:// doi.org/10.1093/chromsci/47.9.825.

ICO. (2019). Total Production by All Exporting Countries. http://www.ico.org/historical/1990\%20onwards/ PDF/1a-total-production.pdf. [1 Mei 2020].

Luksiene, Z., Gudelis, V., Buchovec, I., \& Raudeliuniene, J. (2007). Advanced high-power pulsed light device to decontaminate food from pathogens: effects on salmonella typhimurium viability in vitro. Journal of 
Applied Microbiology, 103(5):1545-1552. https:// doi.org/10.1111/j.1365-2672.2007.03403.x.

Moreira, A.S.P., Nunes, F.M., Domingues, M.R., \& Coimbra, M.A. (2012). Coffee melanoidins: structures, mechanisms of formation and potential health impacts. Food \& Function, 3(9): 903-915. https://doi:10.1039/c2fo30048f.

Nolasco-Perez, I.M., Rocco, L.A.C.M., Cruz-Tirado, J.P., Pollonio, M.A.R., Barbon, S., Barbon, A.P.A.C., \& Barbin, D.F. (2019). Comparison of rapid techniques for classification of ground meat. Biosystems Engineering, 183: 151-159. https:// doi:10.1016/j.biosystemseng.2019.04.013.

Oliveira, R.C.S., Oliveira, L.S., Franca, A.S., \& Augusti, R. (2009). Evaluation of the potential of SPME-GCMS and chemometrics to detect adulteration of ground roasted coffee with roasted barley. Journal of Food Composition and Analysis, 22: 257-261. https://doi.org/10.1016/j.jfca.2008.10.015.

Pauli, E.D., Barbieri, F., Garcia, P.S., Madeira, T.B., Acquaro, V.R., Scarminio, I.S., Camara, C.A.P., \& Nixdorf, S.L. (2014). Detection of ground roasted coffee adulteration with roasted soybean and wheat. Food Research International, 61: 112-119. https://doi.org/10.1016/j.foodres.2014.02.032.

Pizarro, C., Esteban-Díez, I., \& González-Sáiz, J.M. (2007). Mixture resolution according to the percentage of robusta variety in order to detect adulteration in roasted coffee by near infrared spectroscopy. Analytica Chimica Acta, 585(2): 266276. https://doi.org/10.1016/j.aca.2006.12.057.

Reis, N., Botelho, B.G., Franca, A.S., \& Oliveira, L.S. (2017). Simultaneous detection of multiple adulterants in ground roasted coffee by ATR-FTIR spectroscopy and data fusion. Food Analytical Methods, 10(8): 2700-2709. https://doi. org/10.1007/s12161-017-0832-3.

Reis, N., Franca, A.S., \& Oliveira, L.S. (2013a). Performance of diffuse reflectance infrared Fourier transform spectroscopy and chemometrics for detection of multiple adulterants in roasted and ground coffee. LWT-Food Science and Technology, 53:395-401.https://doi.org/10.1016/j. Iwt.2013.04.008.

Reis, N., Franca, A.S., \& Oliveira, L.S. (2013b). Quantitative evaluation of multiple adulterants in roasted coffee by diffuse reflectance infrared Fourier transform spectroscopy (DRIFTS) and chemometrics. Talanta, 115:563-568. https://doi. org/10.1016/j.talanta.2013.06.004.

Ribeiro, M.V.M., Boralle, N., Pezza, H.R., Pezza, L., \& Toci, A.T. (2017). Authenticity of roasted coffee using 1h NMR spectroscopy. Journal of Food Composition and Analysis, 57: 24-30. https://doi. org/10.1016/j.jfca.2016.12.004.

Rodríguez, S.D., Gagneten, M., Farroni, A.E., Percibaldi, N.M., \& Buera, M.P. (2019). FT-IR and untargeted chemometric analysis for adulterant detection in chia and sesame oils. Food Control, 105: 78-85. https://doi.org/10.1016/j.foodcont.2019.05.025.

Roshan, A-R.A., Gad, H.A., El-Ahmady, S.H., Khanbash, M.S., Abou-Shoer, M.I., \& Al-Azizi, M.M. (2013). Authentication of monofloral Yemeni Sidr honey using ultraviolet spectroscopy and chemometric analysis. Journal of Agricultural and Food Chemistry, 61(32):7722-7729.https://doi. org/10.1021/jf402280y.

Sano, E.E., Assad, E.D., Cunha, S.A.R., Correa, T.B.S., \& Rodrigues, H.R. (2003). Quantifying adulteration in roast coffee powders by digital image processing. Journal of Food Quality, 26(2): 123-134. https:// doi.org/10.1111/j.1745-4557.2003.tb00232.x.

Souto, U.T.C.P., Barbosa, M.F., Dantas, H.V., Pontes, A.S., Lyra, W.S., Diniz, P.H.G.D., Araújo, M.C.U., \& Silva, E.C. (2015). Identification of adulteration in ground roasted coffees using uv-vis spectroscopy and SPA-LDA. LWT- Food Science and Technology, 63(2): 1037-1041. https://doi.org/10.1016/j. Iwt.2015.04.003.

Suhandy, D., Yulia, M., Ogawa, Y., \& Kondo, N. (2013). Prediction of I-ascorbic acid using FTIRATR terahertz spectroscopy combined with interval partial least squares (iPLS) regression. Engineering in Agriculture, Environment and Food, 6(3): 111-117. https://doi.org/10.1016/S18818366(13)80020-1.

Suhandy, D., \& Yulia, M. (2017a). The use of partial least square regression and spectral data in uvvisible region for quantification of adulteration in Indonesian palm civet coffee. International Journal of Food Science, 2017:1-7. https://doi. org/10.1155/2017/6274178.

Suhandy, D., \& Yulia, M. (2017b). Peaberry coffee discrimination using uv-visible spectroscopy combined with SIMCA and PLS-DA. International Journal of Food Properties, 20(sup1): S331-S339. https://doi.org/10.1080/10942912.2017.1296861.

Suhandy, D., Yulia, M., Ogawa, Y., \& Kondo, N. (2017). Diskriminasi kopi lanang menggunakan uv-visible spectroscopy dan metode SIMCA. Agritech, 37(4):471-476.https://doi.org/10.22146/ agritech. 12720 .

Wermelinger, T., D’Ambrosio, L., Klopprogge, B., \& Yeretzian, C. (2011). Quantification of the robusta 
fraction in a coffee blend via Raman spectroscopy: proof of principle. Journal of Agricultural and Food Chemistry, 59(17): 9074-9079. https://doi. org/10.1021/jf201918a.

Widaningsih R. 2019. Outlook Kopi. Jakarta: Pusat Data dan Sistem Informasi Pertanian Sekretariat Jenderal - Kementerian Pertanian.

Williams, P. (2007). Grains and seeds. In Near-Infrared Spectroscopy in Food Science and Technology (Ozaki, Y., McClure, W.F. and Christy, A.A), John Wiley \& Sons, Inc. Hoboken, N.J: 165-217.
Williams, P. (2010). The RPD statistic: A tutorial note. NIR News, 25(1): 22-26. https://doi:10.1255/ nirn.1419.

Winkler-Moser, J.K., Singh, M., Rennick, K.A., Bakota, E.L., Jham, G., Liu, S.X., \& Vaughn, S.F. (2015). Detection of corn adulteration in Brazilian coffee (coffea arabica) by tocopherol profiling and nearinfrared (NIR) spectroscopy. Journal of Agricultural and Food Chemistry, 63(49): 10662-10668. https://doi.org/10.1021/acs.jafc.5b04777. 